\title{
Spectrophotometric determination of phosphate in matrices from sequential leaching of sediments
}

\author{
Pierre Anschutz* Jonathan Deborde \\ Université de Bordeaux, CNRS, UMR 5805 EPOC, Talence, France
}

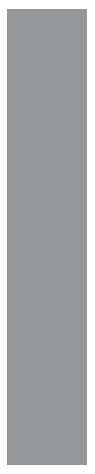

\begin{abstract}
The speciation of Phosphorus (P) in geologic materials can inform diverse investigations in such as aquatic biogeochemistry, soil sciences, and paleo-oceanography. Here, we describe in detail a set of sequential extraction schemes to measure P concentrations from several operationally defined phases: pore water, exchangeable or loosely sorbed P, Fe-bound P, P associated with biogenic apatite, P associated with authigenic apatite and carbonate forms, $\mathrm{P}$ associated with detrital apatite and inorganic forms, and organic P. The two benefits of the procedures we describe compared to prior methodological studies are: (1) fast, simple and inexpensive colorimetric methods have been developed for P determination in all the different matrices; and (2) the Febound phosphorus pool is separated into two fractions, allowing the $\mathrm{P}$ associated with most reactive Fefraction to be distinguished from $\mathrm{P}$ bound to the remainder of the Fe-oxides. Adaptations of these procedures to optimize the characterization of $\mathrm{P}$ pools in a range of material types are also outlined.
\end{abstract}

Phosphorus $(\mathrm{P})$ is a limiting nutrient for primary productivity, and consequently it is thought to control the atmospheric oxygen level on geological time scales (Van Cappellen and Ingall 1994). Phosphorus-rich fertilizer is used in agriculture, and its use has serious implications for future food security (Cordell et al. 2011). Primary P has an igneous origin and occurs mostly as apatite in bedrock, or in uplifted sedimentary deposits. Once P is released from rocks through weathering, dissolved phosphate ions can be transported in natural waters, become adsorbed onto inorganic particles, or be taken up and incorporated into biomass, where P can participate in a variety of different metabolic reactions and pathways (Ruttenberg 2004).

Degradation of organic matter via various heterotrophic metabolic pathways releases orthophosphate to natural waters, where it is available for biological uptake, sorption to mineral phases (Lijklema 1980; Lajtha and Harrison 1995), or incorporation into authigenic minerals such as carbonate fluorapatite (CFA) (e.g., Berner et al. 1993). The adsorption of phosphate on Fe- and Al-oxide and oxyhydroxide has been extensively studied in soil science because phosphorus is a limiting nutrient in terrestrial ecosystems, and sorptive removal of natural or fertilizer phosphorus impacts the production level of crops and forests (e.g., Barrow 1983; Guzman et al. 1994; Frossard et al. 1995). Fe(III) oxides/oxyhydroxides are subject to reductive dissolution, and consequently redox conditions play an important role in P-bioavailability.

*Correspondence: pierre.anschutz@u-bordeaux.fr
The main process of phosphorus removal from the aquatic systems is burial within sediments (Broecker and Peng 1982; Ruttenberg 1992). Exchange between sediment and overlying water takes place through benthic biogeochemical processes, including organic-P mineralization, redox-driven Fe-P cycling, and benthic phosphorus efflux from sediments (Mortimer 1941; Krom and Berner 1980; Sundby et al. 1992). A portion of the pore-water phosphate derived from organic matter mineralization may be adsorbed onto detrital or authigenic iron oxyhydroxides in the oxidized zone of the sediment (e.g., Krom and Berner 1980; Sundby et al. 1992; Slomp and Van Raaphorst 1993; Jensen et al. 1995; Slomp et al. 1996aa,b). Once advected into the reduced zone of sediments through burial or bioturbation, the most reducible fraction of $\mathrm{Fe}(\mathrm{III})$ phases can be solubilized, leading to a release of phosphate (Heggie et al. 1990; Sundby et al. 1992; Anschutz et al. 1998). Eventually, P can be buried over a long period as relict organic-P, P associated with refractory iron oxides, and apatite. Apatite can be formed by igneous, biogenic, and authigenic processes. Authigenic apatite is predominantly CFA that forms sedimentary phosphorite ore and modern phosphorites (Baturin et al. 1972; Jahnke et al. 1983; Froelich 1988; Filippelli 2011). CFA has a greater solubility than igneous apatite, so much so that CFA can be chemically separated from apatite (Ruttenberg 1992). Other authigenic phosphate minerals have been described in marine or lacustrine sediment. For example, vivianite is a ferrous iron phosphate that forms in anoxic or suboxic sediments, where dissolved $\mathrm{Fe}(\mathrm{II})$ can 
accumulate in pore waters (Martens et al. 1978; Ruttenberg and Goni 1997a,b; Anschutz et al. 1999). Biogenic apatite originates from the bones and teeth of vertebrate organisms.

To be able to describe the burial, diagenesis, bioavailability, and residence time of $\mathrm{P}$ in land and aquatic systems, it is necessary to determine $\mathrm{P}$ solid speciation. Because total $\mathrm{P}$ represents generally less than $0.5 \%$ of particle weight, P-bearing phases are difficult to separate from the matrices of most geologic materials. They cannot be detected with mineralogical methods such as X-ray diffraction and scanning electron microscopy, except for in P-rich phosphorites (Schuffert et al. 1990).

Several authors have developed chemical extraction techniques that permit leaching of selectively operationally defined $\mathrm{P}$ fractions such as $\mathrm{P}$ loosely sorbed to particles, $\mathrm{P}$ linked to $\mathrm{Fe}(\mathrm{III})$ phases, apatite and particulate organic-P. Loosely sorbed $\mathrm{P}$ is the fraction that can be easily desorbed in water in response to a decrease in dissolved $\mathrm{P}$ concentration, or an increase in salinity (Fox et al. 1986; Deborde et al. 2007). This exchangeable phosphate pool is determined with rinses of pure water (Psenner et al. 1984), ammonium chloride (Williams et al. 1971), sodium chloride (Li et al. 1973), magnesium chloride (Ruttenberg 1992), or the infinite dilution technique (Aminot and Andrieux 1996).

Several techniques have been developed to extract $P$ bound to $\mathrm{Fe}(\mathrm{III})$ phases. The leaching solution consists of a reducing solution buffered at medium $\mathrm{pH}$. The citratedithionite buffered (CDB) solution (Aguilera and Jackson 1953; Mehra and Jackson 1960) is one of the most often used solution to measure Fe(III)-bound P (Ruttenberg 1992; Jensen and Thamdrup 1993). CDB solution lacks selectivity because dithionite is a strong reducing compound that reduces amorphous and crystalline Fe(III)-oxides and oxyhydroxides. Selective extraction schemes were developed for the partitioning of $\mathrm{Fe}(\mathrm{III})$-phase according to their reactivity (e.g., Poulton and Canfield 2005). Easily reducible oxides (ferrihydrite and lepidocrocite) are selectively leached with hydroxylamine-HCl (Chester and Hughes 1967) and ammonium oxalate solutions (Philips and Lovley 1987), although the latter also reduces magnetite (Poulton and Canfield 2005). An ascorbate solution buffered at $\mathrm{pH} 8$ also extracts selectively the most reactive fraction of Fe(III) (Kostka and Luther 1994). That is why several studies defined the most reactive fraction of Fe-bound $\mathrm{P}$ as the fraction extracted with ascorbate (Anschutz et al. 1998; Caetano and Vale 2002; Rozan et al. 2002; Hyacinthe and Van Cappellen 2004). Phosphorus associated with apatite is generally extracted with a $1 \mathrm{~mol} \mathrm{~L}^{-1} \mathrm{HCl}$ solution (Williams et al. 1971; Williams et al. 1976; Hieltjes and Lijklema 1980; Psenner et al. 1988). Because a large fraction of Fe-bound $P$ also can be dissolved in $1 \mathrm{~mol} \mathrm{~L}^{-1} \mathrm{HCl}$, the partitioning of P-bearing phases needs a sequential extraction procedure (Aspila et al. 1976; Lucotte and D'anglejan 1985; Jensen et al. 1995; Deborde et al. 2007; Ruttenberg et al. 2009) in which loosely sorbed $\mathrm{P}$ is extracted first, then Fe-bound $\mathrm{P}$ is extracted with a reducing solution at near-neutral $\mathrm{pH}$, followed by an acid leaching apatite extraction, and finally organic P forms.

Ruttenberg (1992) and Ruttenberg et al. (2009) made a major improvement by introducing a sodium acetate-extraction step to separate authigenic apatite from detrital apatite in marine sediments. Schenau and De Lange (2000) proposed adding a $\mathrm{NH}_{4} \mathrm{Cl}$ extraction step to separately quantify biogenic hydroxyapatite as distinct from authigenic apatite.

Organic-P can be defined either from the difference between total-P and all extracted inorganic-P forms (Aspila et al. 1976), or from a specific leaching solution at the end of a sequential extraction procedure. Total $\mathrm{P}$ can be obtained from alkaline fusion followed by acid dissolution or from strong-acid dissolution of the residue of sequential extraction. Once the inorganic forms are removed, organic-P can be extracted directly using $\mathrm{HCl}$ after combustion (Lucotte and D'anglejan 1985; Ruttenberg 1992; Jensen et al. 1995). It also can be leached with concentrated sodium hydroxide (Bastula and Krivonosova 1973), with a buffered solution of the surfactant sodium dodecyl sulfate (Vink et al. 1997), or with sulfuric acid (Deborde et al. 2007). $\mathrm{NaOH}$ extraction has been used in soil sciences to define mineralizable organic-P because it does not extract the refractory organic-P fraction (Stewart and Tiessen 1987).

Dissolved inorganic phosphate concentrations are commonly determined with the spectrometric method based on the formation of the blue form of reduced phosphomolybdate (molybdenum blue) (Murphy and Riley 1962). The molybdenum blue method is generally used to measure phosphate from particle leaching when the final matrix does not interfere with colored complex formation. The solution that results from $1 \mathrm{~mol} \mathrm{~L}^{-1} \mathrm{HCl}$ or $\mathrm{H}_{2} \mathrm{SO}_{4}$ leaching, and total residue dissolution are acidic. In such solutions, $\mathrm{P}$ can be analyzed with the Murphy-Riley method only if the solution is highly diluted. This affects the resolution and the precision of measurements. Solutions that contain a reducing agent, such as the ascorbate and the CDB solutions, produce an interference with reduction of phosphomolybdate to form the blue complex. To measure P with the Murphy-Riley method in the $\mathrm{CDB}$ solution, an extraction step is needed (Watanabe and Olsen 1965; Ruttenberg et al. 2009). In this method, the molybdate complex is extracted into isobutanol before reduction with dilute $\mathrm{SnCl}_{2}$. The interferants are left behind in the aqueous phase, having been complexed with $\mathrm{FeCl}_{3}$. This technique works well, but it takes a relatively long time to implement. To simplify the P analysis in CDB extract, Suzumura and Koike (1995) proposed a method based on an extraction technique onto a nonpolar solid phase of extracted phosphate converted into 12-molybdophosphoric acid. The complex adsorbed on the resin is eluted with $\mathrm{NaOH}$ and then determined by the standard molybdenum blue method. HuertaDiaz et al. (2005) proposed to remove P from the CDB solution although alkaline precipitation of $\mathrm{Mg}(\mathrm{OH})_{2}$ by adding $\mathrm{NaOH}$ and $\mathrm{MgCl}_{2}$ according to the MAGIC technique (Karl 
Table 1. Sequential extraction procedure to characterize $P$ fractions in soils, suspended particles and sediments and associated colorimetric method. RM: reagent mixture; S: Sample or standard solution in the resulting matrix. R1: ammonium molybdate solution; R2: sulfuric acid solution; R3: potassium antimony(III) trihydrate oxytartrate solution; R4: ascorbic acid solution. Ratios correspond to volumetric ratios. Hours represent the duration of each extraction step.

\begin{tabular}{|c|c|c|c|}
\hline Amorphous Fe(III)—bound P & $\begin{array}{l}\text { Ascorbate } \\
\left(20 \mathrm{~g} \mathrm{~L}^{-1}\right) \\
24 \mathrm{~h} \\
\mathrm{pH} 8\end{array}$ & $\begin{array}{l}\text { Reduction of amorphous Fe(III)-oxides } \\
\text { and dissolution of associated P }\end{array}$ & $\begin{array}{l}\text { RM: } \\
\text { 4/7R1 + 2/7R2 + 1/7R3 } \\
\text { Cuvette: } \\
0.5 \mathrm{~mL} \text { RM + } 1.3 \mathrm{~mL} \mathrm{~S}+130 \mu \mathrm{L} \mathrm{R} 4\end{array}$ \\
\hline Crystalline Fe(III)—bound P & $\begin{array}{l}\mathrm{CDB} \\
4 \mathrm{~h} \\
\mathrm{pH} 7\end{array}$ & $\begin{array}{l}\text { Dissolution of reducible Fe(III)-oxides } \\
\text { and associated P }\end{array}$ & $\begin{array}{l}\text { RM: } \\
\text { 4/7R1 + 2/7R2 + 1/7R3 } \\
\text { Cuvette: } \\
0.5 \mathrm{~mL} \text { RM }+1.3 \mathrm{~mL} \mathrm{~S}+200 \mu \mathrm{L} \mathrm{R} 4\end{array}$ \\
\hline $\begin{array}{l}\text { Biogenic } \\
\text { hydroxyapatite-bound P }\end{array}$ & $\begin{array}{l}\mathrm{NH}_{4} \mathrm{Cl}\left(2 \mathrm{~mol} \mathrm{~L}^{-1}\right) \\
16 \mathrm{~h} \\
\mathrm{pH} 7\end{array}$ & $\begin{array}{l}\text { Dissolution of biogenic hydroxyapatite } \\
\text { and associated } \mathrm{P}\end{array}$ & $\begin{array}{l}\text { RM: } \\
2 / 5 \mathrm{R} 1+2 / 5 \mathrm{R} 2+1 / 5 \mathrm{R} 3 \\
\text { Cuvette: } \\
350 \mu \mathrm{LM}+2 \mathrm{~mL} \mathrm{~S}+200 \mu \mathrm{L} \mathrm{R} 4\end{array}$ \\
\hline Authigenic CFA—bound P & $\begin{array}{l}\text { Na-acetate }\left(1 \mathrm{~mol} \mathrm{~L}^{-1}\right) \\
16 \mathrm{~h} \\
\mathrm{pH} 4\end{array}$ & $\begin{array}{l}\text { Dissolution of authigenic CFA and } \\
\text { associated P }\end{array}$ & $\begin{array}{l}\text { RM: } \\
2 / 5 \mathrm{R} 1+2 / 5 \mathrm{R} 2+1 / 5 \mathrm{R} 3 \\
\text { Cuvette: } \\
350 \mu \mathrm{L} \mathrm{RM}+2 \mathrm{~mL} \mathrm{~S}+200 \mu \mathrm{L} \mathrm{R} 4\end{array}$ \\
\hline $\begin{array}{l}\text { Detrital apatite and } \\
\text { carbonate- -bound P }\end{array}$ & $\begin{array}{l}\mathrm{HCl}\left(1 \mathrm{~mol} \mathrm{~L}^{-1}\right) \\
16 \mathrm{~h} \\
\mathrm{pH} 2.5\end{array}$ & $\begin{array}{l}\text { Acid dissolution of carbonates and } \\
\text { apatite }\end{array}$ & $\begin{array}{l}\text { RM: } \\
2 / 5 \mathrm{R} 1+2 / 5 \mathrm{R} 2+1 / 5 \mathrm{R} 3 \\
\text { Cuvette: } \\
350 \mu \mathrm{L} \mathrm{RM}+2 \mathrm{~mL} \mathrm{~S}+200 \mu \mathrm{L} 4\end{array}$ \\
\hline Organic-P & $\begin{array}{l}\mathrm{H}_{2} \mathrm{SO}_{4}\left(18 \mathrm{~mol} \mathrm{~L}^{-1}\right) \\
16 \mathrm{~h} \\
\mathrm{pH}<0\end{array}$ & Acid dissolution of organic matter & $\begin{array}{l}\text { RM: } \\
2 / 3 \mathrm{R} 1+1 / 3 \mathrm{R} 3 \\
\text { Cuvette: } \\
150 \mu \mathrm{L} \mathrm{RM}+5 \mathrm{~mL} \mathrm{~S}+100 \mu \mathrm{L} \mathrm{R} 4\end{array}$ \\
\hline
\end{tabular}

and Tien 1992). In this, $P$ is quantitatively sorbed on $\mathrm{Mg}(\mathrm{OH})_{2}$, the precipitate is re-dissolved in $\mathrm{HCl}$ and analyzed with the Murphy-Riley method. Alternatively, the most widely used techniques for P measurement in complex matrix are noncolorimetric methods such as ICP-AES or ICP-MS (Slomp et al. 1996b; Slomp et al. 1998; Schenau and De Lange 2000; Filippelli 2001; Van Der Zee et al. 2002; Harrell and Wang 2007; Machesky et al. 2010).

The aim of this article is to present in detail a simple and standardized method to determine the speciation of $\mathrm{P}$ in geological material. The method can provide information in different areas, such as aquatic biogeochemistry, soil sciences, and paleo-oceanography. Our objective is not to replace the well-established P sequential extraction techniques cited above (e.g., Ruttenberg 1992). Our goal is to focus on two improvements resulting from our work: (1) the separation of iron bound $\mathrm{P}$ pool into two specific fractions, the one that can be easily mobilized through redox changes, and the other that may be fossilized; (2) the development of a colorimetric method for each leaching matrix. For that, we describe in detail a sequential procedure in eight steps that can be used partly or entirely to characterize operationally defined $\mathrm{P}$ fractions in all types of soil, suspended particles and sediments. The first step is the measurement of $\mathrm{P}$ in interstitial water in contact with the solid fraction. The other seven steps are selective leaching procedures of the particulate fraction. The specific colorimetric method determined for each leaching matrix is described. The needed equipment is inexpensive and the work can be done by every laboratory that is able to measure dissolved P colorimetrically.

\section{Materials and procedures}

The first stage of the different extraction steps consists of measuring dissolved phosphate in waters that are in contact 
with particles. For that we use the common molybdenum blue method. In the following, we present the different selective leaching procedures used in our sequential extraction schemes (Table 1). Loosely sorbed $\mathrm{P}$ is extracted using the infinite dilution extrapolation (IDE) after Aminot and Andrieux (1996). Phosphorus associated with Fe(III)-oxides is measured first in an ascorbate solution, which reduces only the amorphous fraction, and second in a CDB solution, which dissolves the remaining crystalline fraction of $\mathrm{Fe}(\mathrm{III})-$ oxides. Then, phosphorus associated with calcium is measured in three successive leaching solutions: ammonium chloride, sodium acetate, and $\mathrm{HCl}\left(1 \mathrm{~mol} \mathrm{~L}^{-1}\right)$, which leach $\mathrm{P}$ from biogenic hydroxyapatite, authigenic CFA, and detrital apatite, respectively. Lastly, organic $P$ is extracted with sulfuric acid. The chemical analysis of extracted phosphate is described in detail. As we present specific variations of the molybdenum blue method for the different extraction steps (Table 1), the different solutions used are briefly presented below (Murphy and Riley 1962).

\section{Phosphate standard solution and reagents (after Murphy and Riley 1962)}

Phosphate standard stock solution $\left(5 \mathrm{mmol} \mathrm{L}{ }^{-1}\right)$ : dry $\mathrm{KH}_{2} \mathrm{PO}_{4}$ in a $100^{\circ} \mathrm{C}$ oven and cool in desiccator. Weigh out $0.6804 \mathrm{~g} \mathrm{KH}_{2} \mathrm{PO}_{4}$ and transfer to a 1000 -mL volumetric flask. Dilute to $1 \mathrm{~L}$ with $\mathrm{MQ}-\mathrm{H}_{2} \mathrm{O}$. This solution is stable for months if stored refrigerated.

R1: ammonium molybdate: $15 \mathrm{~g}\left(\mathrm{NH}_{4}\right)_{6} \mathrm{Mo}_{7} \mathrm{O}_{24}, 4 \mathrm{H}_{2} \mathrm{O}$ in a glass beaker. Add $500 \mathrm{~mL} \mathrm{MQ}-\mathrm{H}_{2} \mathrm{O}$ and stir on magnetic stir plate at $50^{\circ} \mathrm{C}$ until dissolved. Store in a glass bottle in refrigerator; stable in darkness for months.

R2: $2.5 \mathrm{~mol} \mathrm{~L}^{-1} \mathrm{H}_{2} \mathrm{SO}_{4}$ solution (in hood): measure out $140 \mathrm{~mL}$ concentrated $\mathrm{H}_{2} \mathrm{SO}_{4}$ in a $250-\mathrm{mL}$ graduated cylinder and $900 \mathrm{~mL} \mathrm{MQ}-\mathrm{H}_{2} \mathrm{O}$ in a 1-L graduated cylinder. Put one half of the MQ- $\mathrm{H}_{2} \mathrm{O}$ into a 2-L Pyrex glass beaker with a stir bar. Add the $140 \mathrm{~mL} \mathrm{H}_{2} \mathrm{SO}_{4}$ very slowly while stirring on magnetic stir plate. Add slowly the remaining water. Wait until cooling and transfer to a glass bottle. Stable at room temperature.

R3: weigh $0.68 \mathrm{~g} \mathrm{~K}(\mathrm{SbO}) \mathrm{C}_{4} \mathrm{H}_{4} \mathrm{O}_{6}$ and transfer into a glass

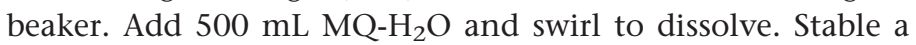
few months stored refrigerated.

R4: L-ascorbic acid solution: weigh $1.08 \mathrm{~g} \mathrm{C}_{6} \mathrm{H}_{8} \mathrm{O}_{6}$ in a vial and add $10 \mathrm{~mL} \mathrm{MQ}-\mathrm{H}_{2} \mathrm{O}$. This is an unstable solution that must be prepared the same day of $\mathrm{P}$ measurement.

\section{Description of the methods}

\section{Colorimetric method for determination of phosphate in (interstitial) water}

The first step consists of measuring dissolved phosphate in waters that are in contact with particles. Pore waters of soils and interstitial waters of sediments collected in rivers, lakes and seas are separated from the particles through centrifugation. For muddy sediments a $50-\mathrm{mL}$ centrifuge tube may be used, and supernatant waters are filtered through a $0.2-\mu \mathrm{m}$ cellulose acetate syringe-membrane. Interstitial waters of sandy sediments and sandy soils are extracted using Vivaspin ${ }^{\mathrm{TM}} 20$ centrifugal extractor tube with $0.2-\mu \mathrm{m}$ PES membrane.

Make standard solutions by diluting the stock solution with $\mathrm{MQ}-\mathrm{H}_{2} \mathrm{O}$ or phosphate-free seawater. Prepare waterR1R2R3 mixed reagent: in a polypropylene 1-L bottle mix $200 \mathrm{~mL} \mathrm{R} 1,500 \mathrm{~mL} \mathrm{R} 2$, and $100 \mathrm{~mL} \mathrm{R} 3$. This solution is stable for months refrigerated in darkness. Mix $10 \mathrm{~mL}$ newly prepared R4 with $40 \mathrm{~mL}$ water-R1R2R3 solution. Put $500 \mu \mathrm{L}$ mixed reagent in every $10 \mathrm{~mL}$ PP tube stored in a rack. Add $5 \mathrm{~mL}$ standard solution or sample to each cuvette. Wait for 5 min and measure at $885 \mathrm{~nm}$ on a spectrophotometer using a $50 \mathrm{~mm}$-long glass cuvette. Measure the blank standard first and zero the spectrophotometer. The $1 \mu \mathrm{mol} \mathrm{L}{ }^{-1}$ standard must be at around 0.100 absorbance unit in these glass cuvettes. For interstitial water of muddy sediments, increase the range of standard solution up to $20 \mu \mathrm{mol} \mathrm{L} \mathrm{L}^{-1}$, and use 10$\mathrm{mm}$ plastic cuvettes. The water-reagent mixture can be done directly in the cuvette $(100 \mu \mathrm{L}$ reagent first and then $1 \mathrm{~mL}$ sample or standard). The standard Murphy and Riley method is suitable to measure $\mathrm{P}$ in the different matrix used to extract loosely sorbed $\mathrm{P}$.

\section{Loosely sorbed $\mathrm{P}$}

Loosely sorbed phosphorus is measured with the IDE. The method is adapted from Aminot and Andrieux (1996). Add $\mathrm{NaHCO}_{3}$ to $2 \mathrm{~L} \mathrm{MQ}-\mathrm{H}_{2} \mathrm{O}$ to bring the $\mathrm{pH}$ to a value close to that of the water in contact with the studied samples (about $8 \mathrm{mg}$ and $80 \mathrm{mg}$ to bring the $\mathrm{pH}$ at 7 and 8 , respectively). Toluene $\left(1 \mathrm{~mL} \mathrm{~L}^{-1}\right)$ can be added to inhibit bacterial activity. $\mathrm{HgCl}_{2}$ is frequently used for poisoning, but it makes an interference to the molybdenum blue method. Weigh $50 \mathrm{mg}$ powdered sample in a 50-mL centrifuge tube. Add $50 \mathrm{~mL}$ $\mathrm{pH}$-buffered water and set on a rotator or a shaker at room temperature for $24 \mathrm{~h}$. Centrifuge for $15 \mathrm{~min}$ at $4000 \mathrm{rpm}$. Pipette $10 \mathrm{~mL}$ supernatant into a $15-\mathrm{mL}$ clean tube for $\mathrm{P}$ analysis. Discard gently the remaining water. Repeat the operation three times to extract almost all the loosely sorbed P. Analyse dissolved phosphorus as in water (see above). Standards should be prepared from blank solutions that were treated by the same procedures and with equal timing as samples. The IDE technique can be done on a separate aliquot when the available particulate material is sufficient. In that case, the obtained concentration of loosely sorbed $\mathrm{P}$ must be subtracted from the ascorbate-P obtained from a separate aliquot.

\section{Ascorbate leaching (amorphous Fe(III)-oxides)}

This technique permits extraction of $\mathrm{P}$ from amorphous Fe(III)-oxides (Anschutz et al. 1998). Weigh $100 \mathrm{mg}$ dry sediment or soil samples into $15-\mathrm{mL}$ centrifuge tubes. Weigh $50 \mathrm{~g}$ Na-citrate and $50 \mathrm{~g} \mathrm{NaHCO}_{3}$ in a 1-L polypropylene

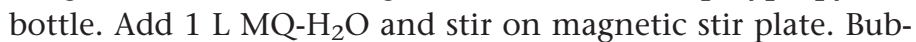
ble the solution with $\mathrm{N}_{2}$ for $5 \mathrm{~min}$. Add gently (because of 
strong effervescence) $20 \mathrm{~g}$ L-ascorbic acid. This solution must be prepared just before utilization. Prepare a $0.2 \mathrm{~mol} \mathrm{~L}^{-1}$ $\mathrm{HCl}$ solution: bring $17.7 \mathrm{~mL}$ concentrated $\mathrm{HCl}(36 \%)$ to $1 \mathrm{~L}$ with $\mathrm{MQ}-\mathrm{H}_{2} \mathrm{O}$. Add $10 \mathrm{~mL}$ ascorbate solution to the $15-\mathrm{mL}$ centrifuge tube with tight sealing caps to prevent leakage while shaking, shake overnight (24 h; Anschutz et al. 2005). Also prepare three blank samples. Centrifuge for $15 \mathrm{~min}$ at $4000 \mathrm{rpm}$. Pipette $1 \mathrm{~mL}$ supernatant into clean $15-\mathrm{mL}$ tubes. Add $9 \mathrm{~mL} 0.2 \mathrm{~mol} \mathrm{~L}^{-1} \mathrm{HCl}$ solution. $\mathrm{P}$ is measured in this (1: 10) diluted solution. Use the blank sample to prepare the matrix for standard solutions: Transfer $25 \mathrm{~mL}$ ascorbate solution in a $250-\mathrm{mL}$ bottle. Dilute to $250 \mathrm{~mL}$ with $0.2 \mathrm{~mol} \mathrm{~L}^{-1}$ HCl. Prepare this matrix at the same time as the samples.

\section{$P$ analysis in the diluted ascorbate matrix}

Make standard solutions ( 0 to $20 \mu \mathrm{mol} \mathrm{L}{ }^{-1}$ ) in the prepared standard matrix. Prepare a mixed reagent by combining $20 \mathrm{~mL} \mathrm{R} 1$ with $10 \mathrm{~mL} 2$ and $5 \mathrm{~mL} \mathrm{R3} \mathrm{(Asc-R1R2R3)} \mathrm{and}$ prepare R4. Add $500 \mu \mathrm{L}$ Asc-R1R2R3 to individual 10-mm square cuvette stored in a rack. Then, add $1.3 \mathrm{~mL}$ sample or standard solution. Add $130 \mu \mathrm{L} \mathrm{R} 4$. Mix with a small plastic stick. Wait $5 \mathrm{~min}$ and measure at $885 \mathrm{~nm}$ on a spectrophotometer. Measure the blank standard first and zero the spectrophotometer. The $5 \mu \mathrm{mol} \mathrm{L^{-1 }}$ standard must have an absorbance of about 0.075 in a $10-\mathrm{mm}$ square spectrophotometric cuvette.

\section{CDB leaching (reducible Fe(III)-oxides)}

This technique permits extraction of $\mathrm{P}$ from amorphous and crystalline Fe(III)-oxides (Lucotte and d'Anglejan 1985; Ruttenberg 1992). The CDB technique can be applied to a separate aliquot when the available particulate material is sufficient. The concentration of ascorbate $\mathrm{P}$ must be subtracted from the value obtained from the CDB leaching to obtain the crystalline fraction of $\mathrm{Fe}(\mathrm{III})$-oxides. Weigh $100 \mathrm{mg}$ dry sediment or soil samples into $15-\mathrm{mL}$ centrifuge tubes. Weigh $44.119 \mathrm{~g}$ Na-citrate and $42.011 \mathrm{~g} \mathrm{NaHCO}_{3}$ in a

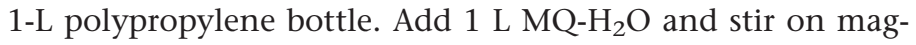
netic stir plate. Bubble the solution with $\mathrm{N}_{2}$ for $5 \mathrm{~min}$. Add $10 \mathrm{~mL}$ of the Na-citrate solution to each $15-\mathrm{mL}$ centrifuge tube. Weigh $0.5625 \mathrm{~g}$ dithionite $\left(\mathrm{Na}_{2} \mathrm{~S}_{2} \mathrm{O}_{4}\right)$ in small weighing dishes and add an aliquot to each tube. Also, prepare three blank samples. Bubble with $\mathrm{N}_{2}$, cap and shake for $4 \mathrm{~h}$. Centrifuge for $15 \mathrm{~min}$ at $4000 \mathrm{rpm}$. Pipette $1 \mathrm{~mL}$ supernatant into clean $15-\mathrm{mL}$ tubes. Add $9 \mathrm{~mL} 0.2 \mathrm{~mol} \mathrm{~L}^{-1} \mathrm{HCl}$ solution. $\mathrm{P}$ is measured in this (1: 10) diluted solution. Use the blank sample to prepare the matrix for standard solutions: Transfer $25 \mathrm{~mL}$ CDB solution in a 250-mL bottle. Dilute to $250 \mathrm{~mL}$ with $0.2 \mathrm{~mol} \mathrm{~L}^{-1} \mathrm{HCl}$. Prepare this matrix at the same time as the samples.

\section{$P$ analysis in the diluted $C D B$ matrix}

Make standard solutions $\left(0-10 \mu \mathrm{mol} \mathrm{L}^{-1}\right)$ in the prepared standard matrix. Leave sample and standard tubes for $24 \mathrm{~h}$ before analysis to allow decomposition of dithionite. Prepare a mixed reagent by combining $20 \mathrm{~mL} \mathrm{R} 1$ with $10 \mathrm{~mL} \mathrm{R} 2$ and
$5 \mathrm{~mL}$ R3 (CDB-R1R2R3) and prepare R4. Add $500 \mu \mathrm{L}$ CDBR1R2R3 to individual 10-mm square cuvette stored in a rack. Then add $1.3 \mathrm{~mL}$ sample or standard solution. Add $200 \mu \mathrm{L}$ R4. Mix with a small plastic stick. Wait $5 \mathrm{~min}$ and measure at $885 \mathrm{~nm}$ on a spectrophotometer. Measure the blank standard first and zero the spectrophotometer.

For the diluted CDB leaching solution, and for the three next leaching procedures described below, the blank remains stable, and the coloration of the standard and samples that contain $\mathrm{P}$ is established within $3 \mathrm{~min}$, but after, the coloration continues to slowly evolve over time. Therefore, it is absolutely necessary to keep the same time interval $( \pm 0.5$ min) between the addition of reagents and the reading of absorbance. For this, the easiest way is to make measurements in sequences of five samples at a time. Prepare the mixture with the reagents in a sequence of five cuvettes. Allow to stand $5 \mathrm{~min}$ and measure the absorbance. Then, again with five other samples. Insert regularly a sequence of five standard solutions to check the reproducibility.

\section{Ammonium chloride $\left(2 \mathrm{~mol} \mathrm{~L}{ }^{-1}\right)$ leaching (biogenic hydroxyapatite)}

This technique permits extraction of $\mathrm{P}$ from biogenic hydroxyapatite after a preliminary CDB leaching (Schenau and De Lange 2000). Weigh $100 \mathrm{mg}$ dry sediment or soil samples into $15-\mathrm{mL}$ centrifuge tubes. Apply the CDB leaching procedure. After centrifugation, discard gently the remaining CDB solution. Rinse tube with $1 \mathrm{~mol} \mathrm{~L}^{-1} \mathrm{MgCl}_{2}$ buffered at $\mathrm{pH}$ 8, centrifuge and discard gently the solution. Weigh $106.98 \mathrm{~g}$

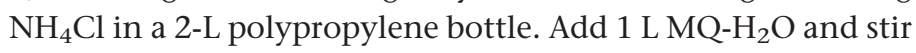
on magnetic stir plate. Add $\mathrm{NaOH}$ to raise the $\mathrm{pH}$ to 7 . Add $10 \mathrm{~mL}$ solution to the $15-\mathrm{mL}$ centrifuge tube. Also, prepare three blank samples. Cap and shake for $16 \mathrm{~h}$. Centrifuge for 15 min at $4000 \mathrm{rpm}$. Pipette $1 \mathrm{~mL}$ supernatant into clean $15-\mathrm{mL}$ tubes. Add $9 \mathrm{~mL} 0.2 \mathrm{~mol} \mathrm{~L}^{-1} \mathrm{HCl}$ solution. $\mathrm{P}$ is measured in this (1: 10) diluted solution. Use the blank sample to prepare the matrix for standard solutions: Transfer $25 \mathrm{~mL} \mathrm{NH}_{4} \mathrm{Cl}$ solution in a $250-\mathrm{mL}$ bottle. Dilute to $250 \mathrm{~mL}$ with $0.2 \mathrm{~mol} \mathrm{~L}^{-1}$ $\mathrm{HCl}$. Prepare this matrix at the same time as the samples.

\section{$P$ analysis in the diluted $\mathrm{NH}_{4} \mathrm{Cl}$ matrix}

Make standard solutions $\left(0-10 \mu \mathrm{mol} \mathrm{L}^{-1}\right)$ in the prepared standard matrix. Prepare a mixed reagent by combining $20 \mathrm{~mL}$ R1 with $20 \mathrm{~mL} \mathrm{R} 2$ and $10 \mathrm{~mL}$ R3 (Ace-R1R2R3) and prepare R4. Add $350 \mu \mathrm{L}$ Ace-R1R2R3 to individual 10-mm square cuvette stored in a rack. Then, add $2 \mathrm{~mL}$ sample or standard solution. Add $200 \mu \mathrm{L} \mathrm{R} 4$. Mix with a small plastic stick. Wait 5 min and measure at $885 \mathrm{~nm}$ on a spectrophotometer. Measure the blank standard first and zero the spectrophotometer. The 5 $\mu \mathrm{mol} \mathrm{L}{ }^{-1}$ standard must have an absorbance of about 0.105 in a 10-mm square spectrophotometric cuvette. Make mixture and measurement through sequences of five samples or standards at a time. 
Sodium acetate $\left(1 \mathrm{~mol} \mathrm{~L}^{-1}\right)$ leaching (authigenic CFA)

This technique permits extraction of $\mathrm{P}$ from authigenic CFA after preliminary $\mathrm{CDB}$ and $\mathrm{NH}_{4} \mathrm{Cl}$ leaching (Ruttenberg 1992). Weigh $100 \mathrm{mg}$ dry sediment or soil samples into 15$\mathrm{mL}$ centrifuge tubes. Apply the $\mathrm{CDB}$, and then the $\mathrm{NH}_{4} \mathrm{Cl}$ leaching procedures. After centrifugation discard gently the remaining $\mathrm{NH}_{4} \mathrm{Cl}$ solution. Rinse tube with $1 \mathrm{~mol} \mathrm{~L}^{-1} \mathrm{MgCl}_{2}$ buffered at $\mathrm{pH} 8$, centrifuge and discard gently the solution. Weigh $136.08 \mathrm{~g}$ Na-acetate in a 2-L polypropylene bottle. Add $1 \mathrm{~L}$ MQ- $\mathrm{H}_{2} \mathrm{O}$ and stir on magnetic stir plate. Add acetic acid to lower the $\mathrm{pH}$ to 4 . Add $10 \mathrm{~mL}$ of this solution to the 15-mL centrifuge tube. Also, prepare three blank samples. Cap and shake for $16 \mathrm{~h}$. Centrifuge for $15 \mathrm{~min}$ at $4000 \mathrm{rpm}$. Pipette $1 \mathrm{~mL}$ supernatant into clean 15-mL tubes. Add $9 \mathrm{~mL}$ $0.2 \mathrm{~mol} \mathrm{~L}^{-1} \mathrm{HCl}$ solution. $\mathrm{P}$ is measured in this (1: 10) diluted solution. Use the blank sample to prepare the matrix for standard solutions: Transfer $25 \mathrm{~mL} \mathrm{Na}$-acetate solution in a 250-mL bottle. Dilute to $250 \mathrm{~mL}$ with $0.2 \mathrm{~mol} \mathrm{~L}^{-1} \mathrm{HCl}$. Prepare this matrix at the same time as the samples.

$P$ analysis in the diluted Na-acetate matrix

The procedure is the same as for the $\mathrm{NH}_{4} \mathrm{Cl}$ matrix.

$\mathrm{HCl}\left(1 \mathrm{~mol} \mathrm{~L}^{-1}\right.$ ) leaching (detrital apatite and carbonates)

This technique permits extraction of inorganic P, except for $\mathrm{P}$ associated with some crystalline Fe(III) phases (Ruttenberg 1992; Berner et al. 1993; Conley et al. 1995). To measure $\mathrm{P}$ from detrital apatite and carbonates, weigh $100 \mathrm{mg}$ dry sediment or soil samples into $15-\mathrm{mL}$ centrifuge tubes. Apply the $\mathrm{CDB}$, the $\mathrm{NH}_{4} \mathrm{Cl}$, and the sodium acetate leaching procedures. After centrifugation discard gently the remaining solution. Rinse tube with $1 \mathrm{~mol} \mathrm{~L}^{-1} \mathrm{MgCl}_{2}$ buffered at $\mathrm{pH} 8$, centrifuge and discard gently the solution. When the $\mathrm{HCl}$ leaching is applied after the CDB leaching, we obtain the $\mathrm{P}$ pool associated with calcium. Measure $80.7 \mathrm{~mL}$ concentrated $\mathrm{HCl}$. Bring to $1 \mathrm{~L}$ with $\mathrm{MQ}-\mathrm{H}_{2} \mathrm{O}$ and stir on magnetic stir plate. Add $10 \mathrm{~mL}$ of this solution to the $15-\mathrm{mL}$ centrifuge tubes. Also, prepare three blank samples. Cap tightly and shake for $16 \mathrm{~h}$. Centrifuge for $15 \mathrm{~min}$ at $4000 \mathrm{rpm}$. Pipette $1 \mathrm{~mL}$ supernatant into clean 15-mL tubes. Add $9 \mathrm{~mL} \mathrm{MQ}-$ $\mathrm{H}_{2} \mathrm{O}$. P is measured in this (1: 10) diluted solution. Use the blank sample to prepare the matrix for standard solutions: Transfer $25 \mathrm{~mL} 1 \mathrm{~mol} \mathrm{~L}^{-1} \mathrm{HCl}$ solution in a $250-\mathrm{mL}$ bottle. Dilute to $250 \mathrm{~mL}$ with $\mathrm{MQ}-\mathrm{H}_{2} \mathrm{O}$. Prepare this matrix at the same time as the samples.

\section{$P$ analysis in the diluted $\mathrm{HCl}$ matrix}

The procedure is the same as for the $\mathrm{NH}_{4} \mathrm{Cl}$ matrix.

\section{$\mathrm{H}_{2} \mathrm{SO}_{4}\left(18 \mathrm{~mol} \mathrm{~L}^{-1}\right)$ leaching (organic-P)}

This technique permits extraction of $\mathrm{P}$ from organic matter after a preliminary $\mathrm{CDB}$ and $1 \mathrm{~mol} \mathrm{~L}^{-1} \mathrm{HCl}$ leaching (Ruttenberg 1992; Berner et al. 1993; Gleyzes et al. 2002; Deborde et al. 2007). After the $1 \mathrm{~mol} \mathrm{~L}^{-1} \mathrm{HCl}$ leaching step, discard gently the remaining $\mathrm{HCl}$ solution. Rinse tube with $\mathrm{MQ}-\mathrm{H}_{2} \mathrm{O}$, centrifuge and discard gently the solution. Dry in an oven at $50^{\circ} \mathrm{C}$. Add carefully $2.5 \mathrm{~mL}$ concentrated $\mathrm{H}_{2} \mathrm{SO}_{4}$ (18 $\mathrm{mol} \mathrm{L}^{-1}, 97-99 \%$ ) in the 15-mL centrifuge tubes. Also, prepare three blank samples. Cap tightly and shake for $16 \mathrm{~h}$. Uncap gently the tube stored in a rack. Set the rack in a cold water bath and dilute three times by adding slowly $5 \mathrm{~mL}$ $\mathrm{MQ}-\mathrm{H}_{2} \mathrm{O}$ to each tube. Cap and shake gently (because of density difference), and centrifuge for $15 \mathrm{~min}$ at $4000 \mathrm{rpm}$. Pipette $210 \mu \mathrm{L}$ supernatant into clean $15-\mathrm{mL}$ tubes. Add $10 \mathrm{~mL}$ MQ- $\mathrm{H}_{2} \mathrm{O}$. P is measured in this final (1: 144) diluted solution. Use the blank sample to prepare the matrix for standard solutions: Transfer $5.25 \mathrm{~mL} 6 \mathrm{~mol} \mathrm{~L}^{-1} \mathrm{H}_{2} \mathrm{SO}_{4}$ solu-

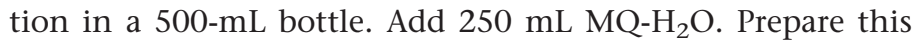
matrix at the same time as the samples.

\section{$P$ analysis in the diluted $\mathrm{H}_{2} \mathrm{SO}_{4}$ matrix}

Make standard solutions ( 0 to $10 \mu \mathrm{mol} \mathrm{L}^{-1}$ ) in the prepared standard matrix. Prepare a mixed reagent by combining $20 \mathrm{~mL}$ R1 with $10 \mathrm{~mL} \mathrm{R} 3\left(\mathrm{H}_{2} \mathrm{SO}_{4}-\mathrm{R} 1 \mathrm{R} 3\right)$. Pipette $5 \mathrm{~mL}$ standard solution or sample in clean $10-\mathrm{mL}$ tubes stored in a rack. In each tube add $150 \mu \mathrm{L} \mathrm{H}_{2} \mathrm{SO}_{4}$-R1R3 and $100 \mu \mathrm{L}$ R4. Swirl to mix and wait $3 \mathrm{~h}$ and measure at $885 \mathrm{~nm}$ on a spectrophotometer using a $50 \mathrm{~mm}$-long glass cuvette. Measure the blank standard first and zero the spectrophotometer.

\section{Assessment and discussion}

All or part of the extraction schemes described above have been used by our research group (e.g., Anschutz et al. 1999, 2007; Deborde et al. 2007, 2008; Canton et al. 2012). These papers provide illustrations of the procedures when applied to riverine, estuarine, and marine suspended particulates and sediments. We believe that our extraction schemes present two major improvements compared with referenced sequential extraction schemes. The first is the separation of the Fe-bound pool into two fractions. The ascorbate solution at $\mathrm{pH} 8$ can only reduce and dissolve the most reducible fraction of $\mathrm{Fe}(\mathrm{III})$-oxides, whereas the CDB solution is much less selective. This has been shown experimentally (Kostka and Luther 1994). Reductive dissolution kinetics of major Fe (oxyhydr)oxides showed two mineral groups (Poulton et al. 2004). Minerals with a lower degree of crystal order (hydrous ferric oxides and lepidocrocite) are reactive on a time-scale of minutes to hours. The more ordered minerals (goethite, magnetite, and hematite) are reactive on a time-scale of tens of days. Dissolution kinetics with CDB solution allows the quantitative dissolution of reducible Fe(III)-oxides.

It can be shown that selectivity of ascorbate is based primarily on reductive power of ascorbate to reduce Fe(III)-oxide phases, i.e., on thermodynamic principles, not kinetics. This can be demonstrated on a thermodynamic equilibrium diagram (Fig. 1). Equilibrium constant $(K)$ of half-redox reactions of $\mathrm{Fe}(\mathrm{III})$-phase reduction for one electron transfer at standard conditions can be compared to ascorbic acid and dithionite oxidation. When the energy yield is favorable, the oxidant species of a redox reaction is that of the half reaction that has 


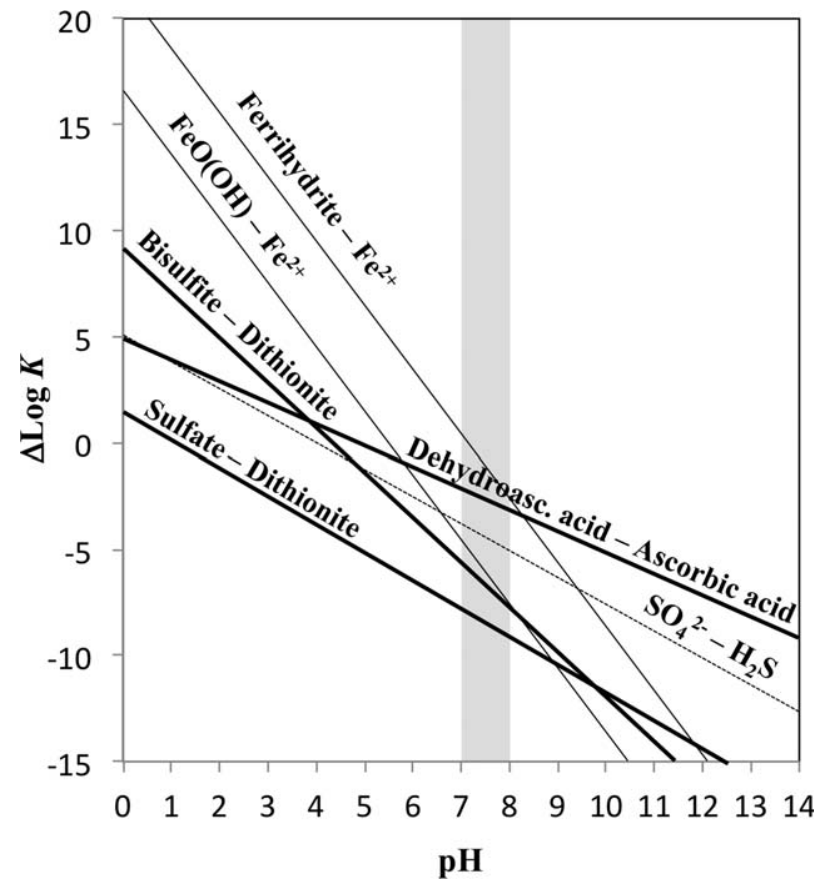

Fig. 1. Variation of $\log K(\Delta \log K)$ vs. $\mathrm{pH}$ with an activity of $10^{-3}$ for $\mathrm{Fe}^{2+}$ for redox couples discussed in the text. The grey area shows the range of $\mathrm{pH}$ during the ascorbate and the $\mathrm{CDB}$ leaching. The energy yield is favorable when the oxidant species of a redox reaction is that of the half reaction that has the highest $\log K$, and the electron donor species is that of the half reaction with the lowest Log $K$. At pH 7-8, ascorbic acid (and $\mathrm{H}_{2} \mathrm{~S}$ ) is a reducing agent for ferrihydrite, but not for goethite, whereas dithionite oxidized to sulfate or bisulfite is a reducing agent for both Fe(III)-phases.

the highest $\log K\left(\right.$ or $\mathrm{pE}^{0}$ ), and the electron donor species is that of the half reaction with the lowest Log $K$. The diagram shows (Fig. 1) that ascorbate extracts selectively the most reducible form of $\mathrm{Fe}(\mathrm{III})$ phases. This fraction is that which is favorably reduced by sulfide (Fig. 1; Canfield et al. 1992) and by $\mathrm{Fe}(\mathrm{III})$ dissimilatory reducing bacteria: the selective extraction of this Fe(III) pool allows quantification of the most reactive form of Fe(III). This fraction also carries much more $\mathrm{P}$ than crystalline Fe(III) phases, mostly because of the nanometric size of ascorbate-extractable Fe-oxides and high reactive surface area (Anschutz et al. 1998). Therefore, the ascorbate extraction allows the part of $\mathrm{P}$ that can be easily mobilized for redox changes to be distinguished from the part linked to Fe that may be buried in sediment or trapped in soils. Fe extracted with ascorbate and CDB can be measured in the 1: 10 diluted matrix with the ferrozine method (Stookey 1970). There is no matrix effect. Nevertheless, the standard solution must be prepared in the blank solution of each matrix.

The second improvement of our extraction schemes is the development of a colorimetric method for P measurement in every matrix. The proportion of reagents in the different matrices has been defined empirically. For R1, R2, and R3, we prepared grids of $1 \mu \mathrm{M}$ standard solutions into which dif- ferent volumes of reagent were added until we obtained a relatively stable molybdenum blue color. Two milliliter standards were pipetted into 64 cuvettes split between four racks in $4 \times 4$ grids. We put 50, 100, 150, and $200 \mu \mathrm{L} \mathrm{R} 1$ in rack 1, 2, 3, and 4, respectively. Then, we added 50, 100, 150 , and $200 \mu \mathrm{L} \mathrm{R} 2$ in each line, and we added the same volume of R3 in each column so that we obtained 64 cuvettes with different proportions of mixed R1R2R3 reagent. Afterward, we added in every cuvette $200 \mu \mathrm{L}$ R4. A blue color appeared only in a few cuvettes, and a stable coloration was observed only in one or two cuvettes. Then, we optimized the detection and the stability using the mixed R1R2R3 reagent that gave the blue color with different proportions of standard solution or R4 reagent until we obtained the best result. The proportions presented above and in Table 1 are optimal recipes we obtained from our investigations. This work was repeated for every matrix each time a new matrix was used in our laboratory.

Absorbance vs. concentration of standard solutions follows the Beer-Lambert law in the range between $0 \mu \mathrm{mol} \mathrm{L} \mathrm{L}^{-1}$ and $20 \mu \mathrm{mol} \mathrm{L}{ }^{-1}$. Calibration relationships are linear in this range of concentration (Fig. 2). This indicates that any problems linked to matrix interferences are insignificant. Colorimetric methods described here do not all have the same reproducibility. The slope of the calibration line remains the same within $10 \%$ deviation every time we do the measurements for the ascorbate matrix (concentration = absorbance $\times 67 \pm 3$ ). This estimate is based on more than 30 ascorbate extraction experiments conducted in our lab since 1999. The slope is more operator-dependent for the other matrices. This is because the coloration evolves slowly with time. The different operators need different times. When the measurement is done with sequences of five samples or standard solutions, the timing can be kept constant, which is a necessary constraint. Nevertheless, when the rhythm of measurement is constant, the absorbance vs concentration of standards is remarkably linear, and the replication of colorimetric measurement of the same sample or standard gives a constant absorbance within $1 \%$ deviation $(n=10)$. Satisfactory reproducibility is obtained when selective leaching is applied on replicate samples. We obtained maximum relative standard deviation of $10 \%(n=10)$. The error is mainly due to the extraction procedure and not to the colorimetric $\mathrm{P}$ analysis. During extractions, differences on replicate samples may be due to heterogeneity of a sample, the weighing of aliquots, measuring the volume of leaching solution, or the dilution of solutions.

The sensitivity of the molybdenum blue method for the ascorbate and the CDB matrix is about 30\% lower than for the water matrix. The precision is generally satisfactory enough for $100 \mathrm{mg}$ sediment or soil samples. The colorimetric method has a sensitivity close to that of water matrix for the acetate, $\mathrm{HCl}$, and $\mathrm{H}_{2} \mathrm{SO}_{4}$ matrices. P concentration values in $\mu \mathrm{mol} \mathrm{\textrm {L } ^ { - 1 }}$ in the final 1: 10 diluted solution in our 


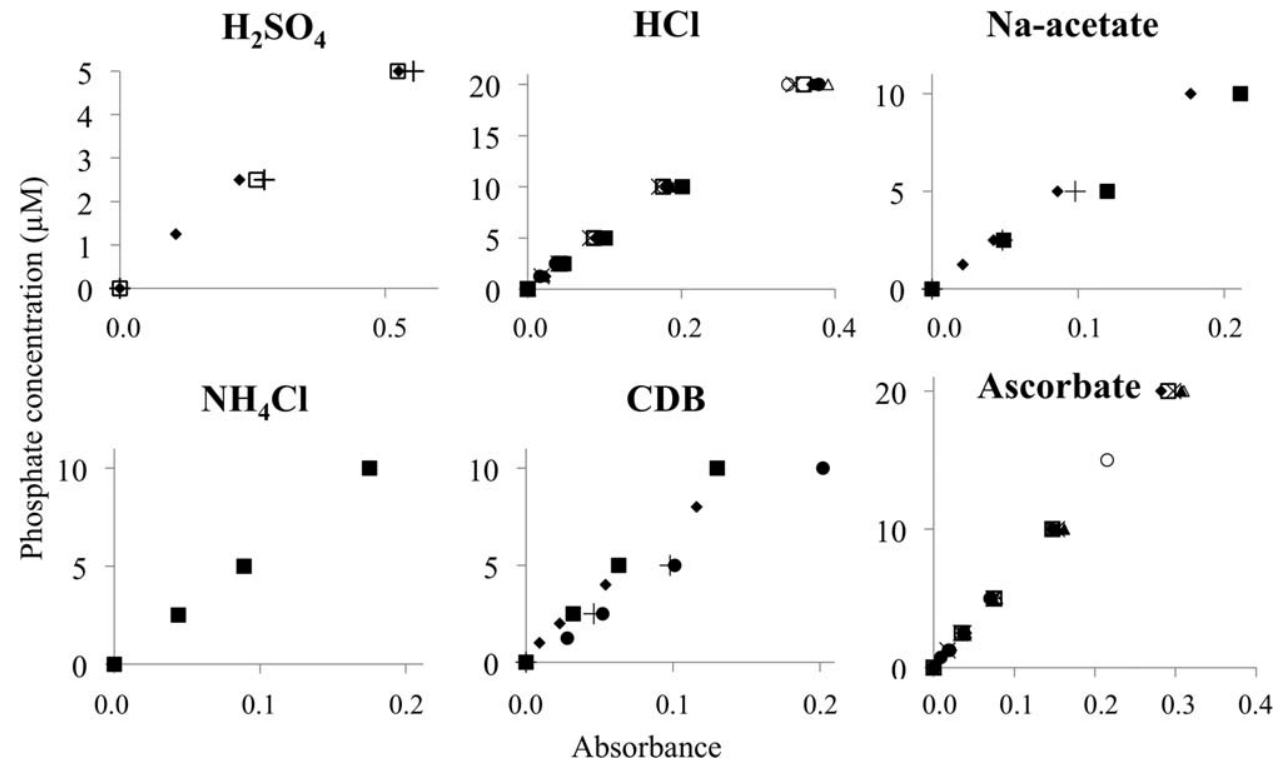

Fig. 2. Phosphate calibration relationships prepared in different matrices of particle leaching. All measurements were made in $10-\mathrm{mm}$ square spectrophotometric cuvettes, except the $\mathrm{H}_{2} \mathrm{SO}_{4}$ series that were measured in 50-mm glass cuvettes. The different symbols represent results from 10 different operators between the years 2003-2012.

experimental method (100 $\mathrm{mg}$ particles in $10 \mathrm{~mL}$ leaching solution) correspond directly to concentration values expressed in $\mu \mathrm{mol} \mathrm{g}^{-1}$ for particulate P. Samples collected in the oxic layer of marine or lacustrine sediment usually need to be diluted because absorbance is out of range. Such samples are frequently enriched in reactive iron oxides and associated $\mathrm{P}$ can be above $20 \mu \mathrm{mol} \mathrm{g}^{-1}$. We also measured concentrations of $\mathrm{P}$ extracted with $\mathrm{Na}$ acetate and $1 \mathrm{~mol} \mathrm{~L}^{-1}$

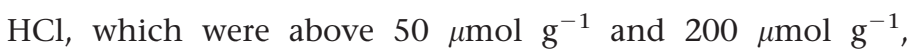
respectively, in surface sediments collected at around $500 \mathrm{~m}$ water depth in the oxygen minimum zone of the Peru margin (unpubl. data). For concentrated samples, the extracted solution must be diluted in the appropriate blank solution.

The detection limit (DL) is that of the spectrophotometer. Using a signal to noise ratio of 3.0 , the DL is 0.003 absorbance unit. This corresponds to a particulate P DL of $0.1 \mu \mathrm{mol}$ $\mathrm{g}^{-1}$ in the $\mathrm{H}_{2} \mathrm{SO}_{4}$ matrix and a DL between $0.15 \mu \mathrm{mol} \mathrm{g}{ }^{-1}$ and $0.20 \mu \mathrm{mol} \mathrm{g}{ }^{-1}$ in the other matrices for the conditions described above. The DL can be improved by measuring the absorbance in a 5 -cm cuvette. If the material is poor in particulate $\mathrm{P}$ concentration, as for instance in sandy sediment, the selective leaching can be performed on $1 \mathrm{~g}$ sample rather than $100 \mathrm{mg}$ sample.

The molybdenum blue method is sensitive to $\mathrm{pH}$. When the sample is an acidified water sample for conditioning or a solution from acid extraction of particulate matter, the initial solution must have a $\mathrm{pH}$ above 1 (Fig. 3). The lower proportion of R2 in diluted extraction matrices relative to the phosphate analysis in water matrix reflects this $\mathrm{pH}$ effect. In the sulfuric acid matrix, R2 is removed from the mixed reagent solution, because sulfuric acid is initially present. The

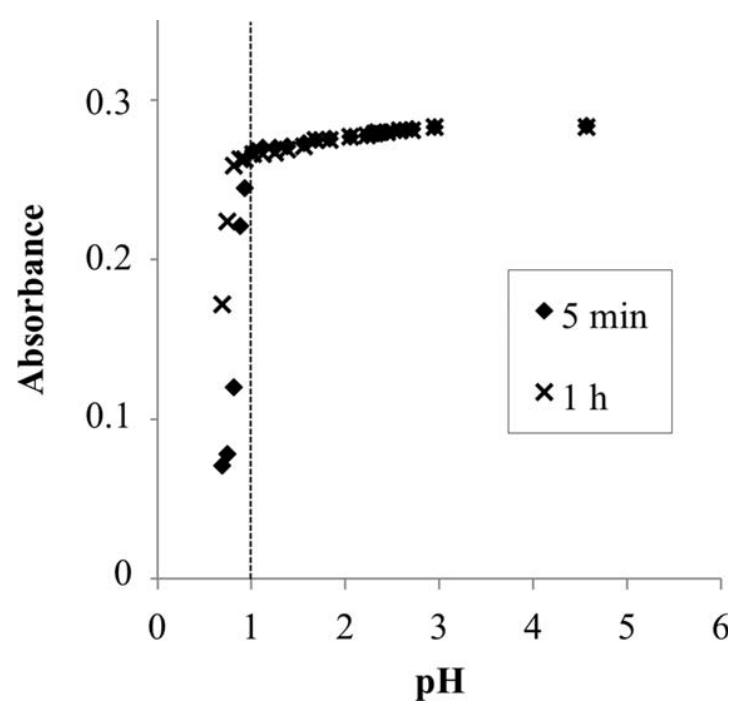

Fig. 3. Molybdenum blue absorbance at $885 \mathrm{~nm}$ vs. $\mathrm{pH}$ of a seawater sample subsampled after successive additions of nitric acid. Initial phosphate concentration was $3 \mu \mathrm{mol} \mathrm{L} \mathrm{L}^{-1}$. Absorbance values were read in a $50-\mathrm{mm}$ glass cuvette $5 \mathrm{~min}$ and $1 \mathrm{~h}$ after the sample-reagent mixture. Below $\mathrm{pH} 1$ the coloration of the sample is not stable: it continues to develop after $5 \mathrm{~min}$.

dilution by 144 of the leaching solution permits a final $\mathrm{H}_{2} \mathrm{SO}_{4}$ concentration similar to that of the reagent-water mixture in the case of the (sea)water matrix.

Dissolved inorganic $\mathrm{P}$ analyses in anoxic pore waters should be done using acidified samples, not in frozen samples, to prevent dissolved $\mathrm{Fe}(\mathrm{II})$ oxidative precipitation and subsequent postsampling phosphate sequestration on Fe(III) 
phases. Nevertheless, the final $\mathrm{pH}$ of the stored sample must be above 1. Pore water sample volume is often small (a few $\mathrm{mL}$ ) when pore waters are extracted from thin horizontal slices of sediment cores. Consequently, acidification must be done with addition of diluted acid. We usually use $50 \mu \mathrm{L}$ or $100 \mu \mathrm{L} \mathrm{1:} 10$ diluted $37 \% \mathrm{HCl}$ solution for $10 \mathrm{~mL}$ fresh water or seawater, respectively.

The chemical extractions were performed on sediment samples dried by lyophilization. Air-drying or lyophilization of anoxic samples may induce the oxidation of Fe-sulfides present in the sediment, and a subsequent enrichment in poorly crystalline Fe-oxides. This oxidation produces protons that can partly dissolve carbonates and apatite. The released phosphate bound to Ca-phases is subsequently adsorbed on the freshly formed iron oxides. Fe sulfide oxidation, thus, leads to a conversion of acetate, $\mathrm{NH}_{4} \mathrm{Cl}$ or $\mathrm{HCl}-\mathrm{P}$ to $\mathrm{Fe}$ bound $\mathrm{P}$ extracted with ascorbate. Such conversion may occur in all reduced samples exposed to oxygen (Kraal et al. 2009). Therefore, for anoxic sediment and soil we recommend to store the samples under inert atmosphere from the sample collection to the sample processing. The extraction schemes can be performed on fresh wet samples to avoid the exposure to air during drying. In that case, the porosity must be measured to calculate the mass of particles that were leached.

\section{Conclusion}

Sequential extraction of phosphorus from natural solids is one of the geochemical tools used to study biogeochemical processes. However, sequential extraction and selective leaching of particles to extract $\mathrm{P}$ from target phases is labor intensive. Thus, fast and reliable approaches to quantify $\mathrm{P}$ in the different matrices issuing from leaching solution are welcome. The first contribution of our work is the implementation of an operationally defined extraction of two different Fe-bound phosphorus pools. The second contribution is the development of different molybdenum blue methods based on matrix-dependent specific mixture of the same reagents used in the colorimetric method to measure dissolved inorganic P in water. The experimental conditions for the analyses have been investigated and optimized. Although an empirical approach was used to obtain optimum recipes, the analytical methodology has the advantages to have an excellent reproducibility, satisfactory DLs, and requires inexpensive equipment. The extraction schemes presented here can be used partly or entirely to characterize operationally defined $\mathrm{P}$ fractions in all types of soil, suspended particulates, and sediments.

\section{References}

Aguilera, N. H., and M. L. Jackson. 1953. Iron oxide removal from soils and clays. Soil Sci. Soc. Am. Proc. 17: 359-364. doi:10.2136/sssaj1953.03615995001700040015x
Aminot, A., and F. Andrieux. 1996. Concept and determination of exchangeable phosphate in aquatic sediments. Water Res. 30: 2805-2811. doi:10.1016/S0043-1354(96)00192-3

Anschutz, P., S. Zhong, B. Sundby, A. Mucci, and C. Gobeil. 1998. Burial efficiency of phosphorus and the geochemistry of iron in continental margin sediments. Limnol. Oceanogr. 43: 53-64. doi:10.4319/lo.1998.43.1.0053

Anschutz, P., C. Hyacinthe, P. Carbonel, J.-M. Jouanneau, and F. Jorissen. 1999. La distribution du phosphore inorganique dans les sediments modernes du golfe de Gascogne. C. R. Acad. Sci. IIA 328: 765-771. doi:10.1016/ S1251-8050(99)80169-4

Anschutz, P., K. Dedieu, F. Desmazes, and G. Chaillou. 2005. Solid speciation, oxidation state, and reactivity of manganese in marine sediments. Chem. Geol. 281: 265-279. doi:10.1016/j.chemgeo.2005.01.008

Anschutz, P., G. Chaillou, and P. Lecroart. 2007. Phosphorus diagenesis in sediment of the Thau Lagoon. Estuar. Coast. Shelf Sci. 72: 447-456. doi:10.1016/j.ecss.2006.11.012

Aspila, K. I., H. Agemian, and A. S. Y. Chau. 1976. A semiautomated method for the determination of inorganic, organic and total phosphate in sediments. Analyst 101: 187-197. doi:10.1039/an9760100187

Barrow, N. J. 1983. A discussion of the methods for measuring the rate of reaction between soil and phosphate. Fertil. Res. 4: 51-61. doi:10.1007/BF01049666

Bastula, A. A., and G. M. Krivonosova. 1973. Phosphorus in the humic and fulvic acids of some Ukrainian soils. Sov. Soil Sci. 5: 347-350.

Baturin, G. H., K. I. Merkulova, and P. I. Chalov. 1972. Radiometric evidence for recent formation of phosphatic nodules in marine shelf sediments. Mar. Geol. 13: M37-M41. doi:10.1016/0025-3227(72)90085-0

Berner, R. A., K. C. Ruttenberg, E. D. Ingall, and J. L. Rao. 1993. The nature of phosphorus burial in modern marine sediments, p. 365-378. In R. Wollast, F. T. Mackenzie and L. Chou [eds.], Interactions of C, N, P and S Biogeochemical Cycles and Global Change. Springer.

Broecker, W. S., and T. H. Peng. 1982. Tracers in the sea. Lamont-Doherty Geological Observatory, Palisades, N. Y.

Caetano, M., and C. Vale. 2002. Retention of arsenic and phosphorus in iron-rich concretions of Tagus salt marshes. Mar. Chem. 79: 261-271. doi:10.1016/S0304-4203(02)00068-3

Canfield, D. E., R. Raiswell, and S. Bottrell. 1992. The reactivity of sedimentary iron minerals toward sulfide. Am. J. Sci. 292: 659-683. doi:10.2475/ajs.292.9.659

Canton, M., P. Anschutz, D. Poirier, R. Chassagne, J. Deborde, and N. Savoye. 2012. Assessment of the buffering capacity of a small estuary on nutrient fluxes originating from the watershed (Leyre estuary, SW France). Estuar. Coast. Shelf Sci. 99: 171-181. doi:10.1016/j.ecss.2011.12.030

Chester, R., and M. J. Hughes. 1967. A chemical technique for the separation of ferro-manganese minerals, carbonate minerals and adsorbed trace elements from pelagic 
sediments. Chem. Geol. 2: 249-262. doi:10.1016/00092541(67)90025-3

Conley, D. J., W. M. Smith, J. C. Cornwell, and T. R. Fisher. 1995. Transformation of particle-bound phosphorus at the land-sea interface. Estuar. Coast. Shelf Sci. 40: 161176. doi:10.1016/S0272-7714(05)80003-4

Cordell, D., A. Rosemarin, J. J. Schröder, and A. L. Smit. 2011. Towards global phosphorus security: A systems framework for phosphorus recovery and reuse options. Chemosphere 84: 747-758. doi:10.1016/j.chemosphere.2011.02.032

Deborde, J., P. Anschutz, G. Chaillou, H. Etcheber, M. V. Commarieu, P. Lecroart, and G. Abril. 2007. The dynamics of phosphorus in turbid estuarine systems: Example of the Gironde estuary (France). Limnol. Oceanogr. 52: 862872. doi:10.4319/lo.2007.52.2.0862

Deborde, J., and others. 2008. Role of the tidal pumping on nutrient cycling in a temperate lagoon (Arcachon Bay, France). Mar. Chem. 109: 98-114. doi:10.1016/ j.marchem.2007.12.007

Filippelli, G. M. 2001. Carbon and phosphorus cycling in anoxic sediments of the Saanich Inlet (British Columbia). Mar. Geol. 174: 307-321. doi:10.1016/S0025-3227(00)00157-2

Filippelli, G. M. 2011. Phosphate rock formation and marine phosphorus geochemistry: The deep time perspective. Chemosphere 84: 759-766. doi:10.1016/j.chemosphere.2011.02.019

Fox, L. E., S. L. Sager, and S. C. Wofsy. 1986. The chemical control of soluble phosphorus in the Amazon estuary. Geochim. Cosmochim. Acta 50: 783-794. doi:10.1016/00167037(86)90354-6

Froelich, P. N. 1988. Kinettic control of dissolved phosphate in natural rivers and estuaries: A primer on the phosphate buffer mechanism. Limnol. Oceanogr. 33: 649-668. doi: 10.4319/1o.1988.33.4_part_2.0649

Frossard, E., M. Brossard, M. J. Hedley, and A. Meterell. 1995. Reactions controlling the cycling of $\mathrm{P}$ in soils, p. 107-137. In H. Tiessen [ed.], Phosphorus in the global environment, SCOPE 54 . Wiley.

Gleyzes, C., S. Tellier, and M. Astruc. 2002. Fractionation studies of trace elements in contaminated soils and sediments: A review of sequential extraction procedures. Trends Anal. Chem. 21: 451-467. doi:10.1016/S01659936(02)00603-9

Guzman, G., E. Alcantara, M. Barron, and J. Torrent. 1994. Phytoavailability of phosphate adsorbed on ferrihydrite, hematite and goethite. Plant Soil 159: 219-225. doi: 10.1007/BF00009284

Harrell, D. L., and J. J. Wang. 2007. Evaluation of three- and five-step inorganic phosphorus chemical fractionation procedures along with inductively coupled plasma determination for calcareous soils. Soil Sci. Soc. Am. Proc. 174: 55-67. doi:10.1097/01.ss.0000235849.48320.4a

Heggie, D. T., and others. 1990. Organic carbon cycling and modern phosphorite formation on the east Australian continental margin: An overview, p. 87-117. In A. G. J.
Notholt and I. I. Jarvis [eds.], Phosphorite research and development. Geological Society Special Publication.

Hieltjes, A. H. M., and L. Lijklema. 1980. Fractionation on inorganic phosphates in calcareous sediments. J. Environ. Qual. 9: 405-407. doi:10.2134/jeq1980.00472425000900030015x

Huerta-Diaz, M. A., A. Tovar-Sanchez, G. Filippelli, J. Latimer, and S. A. Sañudo-Wilhelmy. 2005. A combined CDB-MAGIC method for the determination of phosphorus associated with sedimentary iron oxyhydroxides. Appl. Geochem. 20: 2108-2115. doi:10.1016/j.apgeochem. 2005.07.009

Hyacinthe, C., and P. Van Cappellen. 2004. An authigenic iron phosphate phase in estuarine sediments: Composition, formation and chemical reactivity. Mar. Chem. 91: 227-251. doi:10.1016/j.marchem.2004.04.006

Jahnke, R. A., S. R. Emerson, K. H. Kim, and W. C. Burnett. 1983. The present day formation of apatite in Mexican continental margin sediments. Geochim. Cosmochim. Acta 47: 259-266. doi:10.1016/0016-7037(83)90138-2

Jensen, H. S., and B. Thamdrup. 1993. Iron bound phosphorus in marine sediments as measured by bicarbonatedithionite extraction. Hydrobiologia 253: 47-59. doi: 10.1007/BF00050721

Jensen, H. S., P. B. Mortensen, F. O. Andersen, E. Rasmussen, and A. Jensen. 1995. Phosphorus cycling in coastal marine sediment, Aarhus Bay, Denmark. Limnol. Oceanogr. 40: 908-917. doi:10.4319/lo.1995.40.5.0908

Karl, D. M., and G. Tien. 1992. MAGIC: A sensitive and precise method for measuring dissolved phosphorus in aquatic environments. Limnol. Oceanogr. 37: 77-96. doi: 10.4319/lo.1992.37.1.0105

Kostka, J. E., and G. W. Luther. 1994. Partitioning and speciation of solid phase iron in saltmarsh sediments. Geochim. Cosmochim. Acta 58: 1701-1710. doi:10.1016/ 0016-7037(94)90531-2

Kraal, P., C. P. Slomp, A. Forster, M. M. M. Kuypers, and A. Sluijs. 2009. Pyrite oxidation during sample storage determines phosphorus fractionation in carbonate-poor anoxic sediments. Geochim. Cosmochim. Acta 73: 3277-3290. doi:10.1016/j.gca.2009.02.026

Krom, M. D., and R. A. Berner. 1980. Adsorption of phosphate in anoxic marine sediments. Limnol. Oceanogr. 25: 797-806. doi:10.4319/lo.1980.25.5.0797

Lajtha, K., and A. F. Harrison. 1995. Strategies of phosphorus acquisition and conservation by plant species and communities, p. 139-147. In H. Tiessen [ed.], Phosphorus in the global environment, SCOPE 54 . Wiley.

Li, W. C., D. E. Armstrong, and R. F. Harris. 1973. Measurement of exchangeable inorganic phosphate in lake sediments. Environ. Sci. Technol. 7: 454-557. doi:10.1021/ es60077a006

Lijklema, L. 1980. Interaction of orthophosphate with iron (III) and aluminum hydroxide. Environ. Sci. Technol. 14: 537-541. doi:10.1021/es60165a013 
Lucotte, M., and B. D'anglejan. 1985. A comparison of several methods for the determination of iron hydroxides and associated orthophosphates in estuarine particulate matter. Chem. Geol. 48: 257-264. doi:10.1016/0009-2541(85)90050-6

Machesky, M. L., T. R. Holm, and J. A. Slowikowski. 2010. Phosphorus speciation in stream bed sediments from an agricultural watershed: Solid-phase associations and sorption behavior. Aquat. Geochem. 16: 639-662. doi: 10.1007/s10498-010-9103-2

Martens, C. S., R. A. Berner, and J. K. Rosenfeld. 1978. Interstitial water chemistry of anoxic Long Island Sound Sediments: 2. Nutrient regeneration and phosphate removal. Limnol. Oceanogr. 23: 605-617. doi:10.4319/lo.1978.23.4.0605

Mehra, O. P., and M. L. Jackson. 1960. Iron oxide removal from soils and clays by a dithionite-citrate system buffered with sodium bicarbonate. Clays Clay Miner. 7: 317327. doi:10.1016/B978-0-08-009235-5.50026-7

Mortimer, C. H. 1941. The exchange of dissolved substances between mud and water in lakes. J. Ecol. 29: 280-320. doi: $10.2307 / 2256395$

Phillips, E. J. P., and D. R. Lovley. 1987. Determination of Fe(III) and Fe(II) in oxalate extracts of sediment. Soil Sci. Soc. Am. J. 51: 938-941. doi:10.2136/sssaj1987.03615995005100040021x

Poulton, S. W., M. D. Krom, and R. Raiswell. 2004. A revised scheme for the reactivity of iron (oxyhydr)oxide minerals towards dissolved sulfide. Geochim. Cosmochim. Acta 68: 3703-3715. doi:10.1016/j.gca.2004.03.012

Poulton, S. W., and D. E. Canfield. 2005. Development of a sequential extraction procedure for iron: Implications for iron partitioning in continentally derived particulates. Chem. Geol. 214: 209-221. doi:10.1016/j.chemgeo.2004. 09.003

Murphy, J., and J. P. Riley. 1962. A modified single solution method for determination of phosphate in natural waters. Anal. Chem. Acta 42: 31-36. doi:10.1016/S00032670(00)88444-5

Psenner, R., R. Pucsko, and M. Sager. 1984. Die Fraktionierung organischer und anorganischer Phosphorverbindungen von Sedimenten. Versuch einer Definition ökologisch wichtiger Fraktionen. Arch. Hydrobiol. Suppl. 70: 111155.

Psenner, R., B. Boström, M. Dinka, K. Pettersson, R. Pucsko, and M. Sager. 1988. Fractionation of phosphorus in suspended matter and sediment. Arch. Hydrobiol. Beih. Ergebn. Limnol. 30: 98-110.

Rozan, T. F., and others. 2002. Iron-sulfur-phosphorus cycling in the sediments of a shallow coastal bay: Implications for sediment nutrient release and benthic macroalgal blooms. Limnol. Oceanogr. 47: 1346-1354. doi: 10.4319/1o.2002.47.5.1346

Ruttenberg, K. C. 1992. Development of a sequential extraction method for different forms of phosphorus in marine sediments. Limnol. Oceanogr. 37: 1460-1482. doi: 10.4319/1o.1992.37.7.1460
Ruttenberg, K. C. 2004. The global phosphorus cycle, p. 585-643. In H. D. Holland and K. K. Turekian [eds.], Treatise on geochemistry. Elsevier Science.

Ruttenberg, K. C., and M. A. Goni. 1997a. Depth trends in phosphorus distribution and $\mathrm{C}: \mathrm{N}: \mathrm{P}$ ratios of organic matter in Amazon Fan sediments: Indices of organic matter source and burial history, p. 505-517. In R. D. Flood, D. J. W. Piper, A. Klaus and L. C. Peterson [eds.], Proced. Ocean Drilling Programme Sci. Res. College Station, TX, Vol. 155.

Ruttenberg, K. C., and M. A. Goni. 1997b. Phosphorus distribution, elemental ratios, and stable carbon isotopic composition of arctic, temperate, and tropical coastal sediments: Tools for characterizing bulk sedimentary organic matter. Mar. Geol. 139: 123-145. doi:10.1016/ S0025-3227(96)00107-7

Ruttenberg, K. C., N. O. Ogawa, F. Tamburini, R. A. Briggs, N. D. Colasacco, and E. Joyce. 2009. Improved, highthroughput approach for phosphorus speciation in natural sediments via the SEDEX sequential extraction method. Limnol. Oceanogr.: Methods 7: 319-333. doi: 10.4319/lom.2009.7.319

Schenau, S. J., and G. J. De Lange. 2000. A novel chemical method to quantify fish debris in marine sediments. Limnol. Oceanogr. 45: 963-971. doi:10.4319/lo.2000.45.4.0963

Schuffert, J. D., M. Kastner, G. Emanuele, and R. A. Jahnke. 1990. Carbonate-ion substitution in francolite: A new equation. Geochim. Cosmochim. Acta 54: 2323-2328. doi:10.1016/0016-7037(90)90058-S

Slomp, C. P., and W. Van Raaphorst. 1993. Phosphate adsorption in oxidized marine sediments. Chem. Geol. 107: 477-480. doi:10.1016/0009-2541(93)90235-B

Slomp, C. P., E. H. G. Epping, W. Helder, and W. A. Van Raaphorst. 1996a. A key role for iron-bound phosphorus in authigenic apatite formation in North Atlantic continental platform sediments. J. Mar. Res. 54: 1179-1205. doi:10.1357/0022240963213745

Slomp, C. P., S. J. Van Der Gaast, and W. Van Raaphorst. 1996b. Phosphorus binding by poorly crystalline iron oxides in North Sea sediments. Mar. Chem. 52: 55-73. doi:10.1016/0304-4203(95)00078-X

Slomp, C. P., J. F. P. Malschaert, and W. Van Raaphorst. 1998. The role of adsorption in sedimentwater exchange of phosphate in North Sea continental margin sediments. Limnol. Oceanogr. 43: 832-846. doi:10.4319/lo.1998.43.5.0832

Stewart, J. W. B., and H. Tiessen. 1987. Dynamics of soil organic phosphorus. Biogeochemistry 4: 41-60. doi: 10.1007/BF02187361

Stookey, L. L. 1970. Ferrozine-A new spectrophotometric reagent for iron. Anal. Chem. Acta 42: 779-781. doi: 10.1021/ac60289a016

Sundby, B., C. Gobeil, N. Silverberg, and A. Mucci. 1992. The phosphorus cycle in coastal marine sediments. Limnol. Oceanogr. 37: 1129-1145. doi:10.4319/1o.1992.37.6.1129 
Suzumura, M., and K. Koike. 1995. Application of solidphase extraction technique for determination of phosphorus in sediment extract. Geochem. J. 29: 331-335. doi: 10.2343/geochemj.29.331

Van Cappellen, P., and E. D. Ingall. 1994. Redox stabilization of the atmosphere by phosphorus-limited marine productivity. Science 271: 493-496. doi:11541251

Van Der Zee, C., C. P. Slomp, and W. Van Raaphorst. 2002. Authigenic $\mathrm{P}$ formation and reactive $\mathrm{P}$ burial in sediments of the Nazare canyon on the Iberian margin (NE Atlantic). Mar. Geol. 185: 379-392. doi:10.1016/S0025-3227(02)00189-5

Vink, S., R. M. Chambers, and S. V. Smith. 1997. Distribution of phosphorus in sediments from Tomales Bay, California. Mar. Geol. 139: 157-179. doi:10.1016/S00253227(96)00109-0

Watanabe, F. S., and S. R. Olsen. 1965. Test of an ascorbic acid method for determining phosphorus in water and NaHCO3 extracts from soil. Soil Sci. Soc. Am. Proc. 29: 677-678. doi:10.2136/sssaj1965.03615995002900060025x

Williams, J. D. H., J. K. Syers, R. F. Harris, and D. E. Armstrong. 1971. Fractionation of inorganic phosphate in calcareous lake sediments. Soil Sci. Soc. Am. Proc. 35: 250-255. doi:10.2136/sssaj1971.03615995003500020023x

Williams, J. D. H., J.-M. Jaquet, and R. L. Thomas. 1976. Forms of phosphorus in the surficial sediments of Lake Erie. J. Fish. Res. Board Can. 33: 416-429. doi:10.1139/ f76-063

\section{Acknowledgments}

We thank C. Reimers for editorial improvements of the manuscript. Two anonymous reviewers are thanked for their constructive comments. This is a contribution of the projects INSU-PROOF Oxybent, ANR-Blanc IZOFLUX, and the "Projet innovant EPOC-2012". The assistance of Christelle Hyacinthe, Gwénaëlle Chaillou, Amandine Coizic, Bruno Labrousse, Ludovic LeGuern, Philippe Martinez, Amandine Kehil, Aurélia Mouret, Séverine Rouillard, Céline Charbonnier and Anne Rapin for help in laboratory and sampling is greatly acknowledged.

Submitted 26 September 2015

Revised 4 December 2015

Accepted 14 December 2015

Associate editor: Clare Reimers 